\title{
Mortality after cancer diagnosis among HIV- infected individuals in the CFAR Network of Integrated Clinical Systems (CNICS)
}

\author{
Chad Achenbach ${ }^{1 *}$, Stephen Cole ${ }^{2}$, Corey Casper ${ }^{3}$, Mari Kitahata ${ }^{3}$, James Willig ${ }^{4}$, Michael Mugavero ${ }^{4}$, \\ Michael Saag ${ }^{4}$ \\ From $12^{\text {th }}$ International Conference on Malignancies in AIDS and Other Acquired Immunodeficiencies \\ (ICMAOI) \\ Bethesda, MD, USA. 26-27 April, 2010
}

\section{Background}

Increased cancer risk has been well established in several HIV-infected populations. However, studies investigating mortality after a diagnosis of cancer have been limited in size, scope, and HIV-specific risk factors.

\section{Materials and methods}

CNICS is a cohort of over 20,000 HIV-infected adults in clinical care at eight U.S. sites. We included patients with chart review verified incident cancer diagnoses between 1996 and 2009. Non-AIDS defining cancers (NADC) were categorized as infection (HPV, EBV, or $\mathrm{HBV} / \mathrm{HCV}$ )-related [1]: squamous cell anal, squamous cell oral cavity/pharynx, penis, vagina/vulva, Hodgkins, and liver; or non-infection-related: all other NADCs. Death was confirmed by the National Death Index and/ or state death certificate data. We examined independent predictors of mortality by employing Cox proportional hazards regression models.

\section{Results}

918 adults with HIV and cancer were included in this analysis. 55\% had AIDS-defining cancer (ADC), 15\% had infection-related NADC, and $30 \%$ had non-infection related NADC. At cancer diagnosis, median age was 43 years, $50 \%$ were white, $86 \%$ male, $19 \%$ IDU, $21 \% \mathrm{HBV} /$ HCV, 46\% current smokers, and 56\% current alcohol drinkers. Median CD4+ cell count was 192 cells $/ \mathrm{mm}^{3}$ and HIV RNA was $3.6 \log _{10}$ copies/ml. There were 395

\footnotetext{
* Correspondence: c-achenbach@northwestern.edu

${ }^{1}$ Division of Infectious Diseases, Northwestern University, Chicago, IL, USA

Full list of author information is available at the end of the article
}

Table 1

\begin{tabular}{lll}
\hline & $\begin{array}{l}\text { Mortality Hazard } \\
\text { Ratio* }\end{array}$ & $\begin{array}{l}\mathbf{9 5 \%} \\
\text { Confidence } \\
\text { Limits }\end{array}$ \\
\hline Age, per 10 years & 1.23 & $1.09,1.40$ \\
White & 0.77 & $0.62,0.95$ \\
Male & 1.06 & $0.78,1.44$ \\
HBV/HCV & 1.11 & $0.86,1.43$ \\
IDU & 1.31 & $1.00,1.70$ \\
Smoking: & &
\end{tabular}

Smoking:

$\begin{array}{lll}\text { Never } & 1 & - \\ \text { Former } & 1.51 & 1.08,2.12 \\ \text { Current } & 1.45 & 1.04,2.02\end{array}$

Alcohol intake:

$\begin{array}{lll}\text { Never } & 1 & - \\ \text { Former } & 0.99 & 0.72,1.36 \\ \text { Current } & 0.78 & 0.58,1.04\end{array}$

HIV RNA, per $\log _{10}$ copies/ml 1.09 $1.01,1.17$

CD4 count:

$$
\begin{array}{ll}
>500 \text { cells } / \mathrm{mm}^{3} & 1 \\
200-500 \text { cells } / \mathrm{mm}^{3} & 1.11 \\
<200 \text { cells } / \mathrm{mm}^{3} & 1.57
\end{array}
$$

Summary cancer type:

\begin{tabular}{lll} 
ADC & 1 & - \\
Infection-related & & \\
NADC & 0.78 & $0.55,1.11$ \\
$\begin{array}{l}\text { Non-infection- } \\
\text { related NADC }\end{array}$ & 1.38 & $1.05,1.82$ \\
\hline
\end{tabular}

*Adjusted for all variables in the table. 


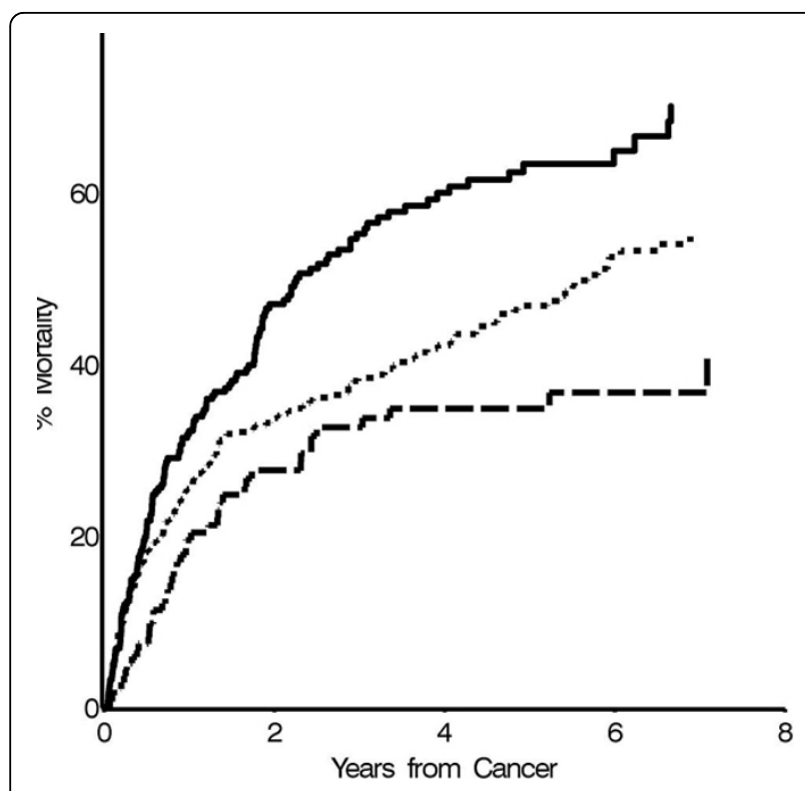

Figure 1 Mortality after cancer diagnosis for 918 HIV+ adults by cancer type. Non-infection-related NADC is solid line, ADC is dotted line, and infection-related NADC is dashed line.

deaths in 2,393 person-years of follow-up for a crude mortality rate of 16.5 per 100 person-years (95\% CL: 15.0, 18.2). Adjusted hazard of mortality was significantly increased among individuals who were older, non-white, IDU, current or former smokers, had lower CD4+ cell count, higher HIV RNA, and non-infection related NADC (see Table 1). Figure 1 shows cumulative mortality after cancer diagnosis stratified by type of cancer.

\section{Conclusions}

In the era of ART, unique independent predictors of mortality among individuals with HIV and cancer were level of immune suppression, degree of HIV RNA replication, and non-infection-related type of cancer. These data highlight the need to improve prevention and management of NADC in this population.

\section{Acknowledgements}

These findings are presented on behalf of the CNICS. Funding for this study was provided by NIAID and NCI.

This article has been published as part of Infectious Agents and Cancer Volume 5 Supplement 1, 2010: Proceedings of the $12^{\text {th }}$ International Conference on Malignancies in AIDS and Other Acquired

Immunodeficiencies (ICMAOI).The full contents of the supplement are available online at http://www.biomedcentral.com/1750-9378/5?issue=S1.

\section{Author details}

'Division of Infectious Diseases, Northwestern University, Chicago, IL, USA 2Department of Epidemiology, University of North Carolina at Chapel Hill, Chapel Hill, NC, USA. 'Division of Allergy and Infectious Diseases, University of Washington, Seattle, WA, USA. ${ }^{4}$ Division of Infectious Diseases, University of Alabama at Birmingham, Birmingham, AL, USA.
Published: 11 October 2010

doi:10.1186/1750-9378-5-S1-A56

Cite this article as: Achenbach et al:: Mortality after cancer diagnosis among HIV-infected individuals in the CFAR Network of Integrated Clinical Systems (CNICS). Infectious Agents and Cancer 2010 5(Suppl 1):A56.
Submit your next manuscript to BioMed Central and take full advantage of:

- Convenient online submission

- Thorough peer review

- No space constraints or color figure charges

- Immediate publication on acceptance

- Inclusion in PubMed, CAS, Scopus and Google Scholar

- Research which is freely available for redistribution 